\title{
Synthetic vaccine only a distant prospect
}

\section{Atlanta, Georgia}

THE virus responsible for acquired immune deficiency syndrome (AIDS) in humans may have entered the population recently by transmission from monkeys, according to a study of African green monkeys by Max Essex of Harvard University. Essex has found that apparently healthy monkeys show strong antibody recognition of STLV-III, a virus associated with immune deficiency disease in rhesus macaques which has many similarities with human AIDS virus. A simian origin for the virus would be consistent with new data suggesting that AIDS may have been present in humans of central Africa since before 1973.

Essex reported his findings here at the first international conference on AIDS, attended by two thousand researchers from 26 countries. The meeting was sponsored by the US Department of Health and Human Services and the World Health Organization, among others. The availability of two different primate models of AIDS, one with disease and one without, should be invaluable for development of an AIDS vaccine: comparisons between viruses might indicate those conserved regions that might be most usefully imitated in a synthetic vaccine produced by genetic engineering, so avoiding the problems caused by antigenic variability.

A vaccine that would prime the immune system to deal with the AIDS virus is one of the best hopes for dealing with the disease; it seems unlikely that a treatment will be found that will eradicate the infection once it becomes established in an individual, where DNA copies of the virus are incorporated into the host's own DNA. James Curran, head of the AIDS task force at the Center for Disease Control (CDC), said that if a vaccine became available it might be necessary to vaccinate all US citizens, starting first with those in high risk groups who at present show no evidence of infection. A vaccine is still several years away, however.

The latest data on the spread of AIDS in the United States are grim but unsurprising. By last week 9,608 cases had been diagnosed of which 4,712 have been fatal. Estimates of the number of US citizens who have already been infected with the AIDS virus, as indicated by the presence of serum antibodies, range from 0.5 to 1.0 million; more than 10 per cent of these are likely to develop the disease over the next five years, even if all further transmission of the virus stops immediately. The doubling period for the number of reported cases in the United States has increased slightly, but is still around 8-9 months. Principal con- clusions from the conference have been reported to the US Department of Health and Human Services, and a separate report is being prepared for the World Health Organization.

New estimates have been made of the latency period between infection and the onset of disease symptoms, and it seems that the mean latency may be five years or even longer; this suggests that many people in high risk groups may already have been infected but are clinically unaware of the fact.

Between 70 and 90 per cent of haemophiliacs who receive regular infusions of factor VIII concentrate have detectable serum antibodies to the AIDS virus, and some data suggest that more than five per cent of these are likely to develop AIDS, with a further number developing "lesser AIDS" - AIDS-like symptoms that nevertheless fall outside CDC's definition of AIDS (Elaine Eyster, Pennsylvania State University School of Medicine). Estimates of the proportion of people with antibodies who will develop the disease are likely to go on increasing. Among one group of New York promiscuous homosexuals, the proportion of those with antibody that have developed AIDS is as high as 20 per cent (J Goedert, National Cancer Institute); it is not yet clear whether this high figure is due to some complicating lifestyle factor or whether it is because the virus has been present for longer in that group.

Very preliminary data from wives of haemophiliacs suggest that the AIDS virus is transmitted heterosexually by repeated contacts from male to female (J. Goedert, National Cancer Institute). A claim for female to male heterosexual transmission from prostitutes was also made ( $R$. Redfield, Walter Reed Army Medical Center), though these data are also equivocal.

Some modestly encouraging results for treatment of AIDS with anti-viral drugs were reported, although none amounted to a major breakthrough. It is now apparent that neurological symptoms such as dementia are present in high proportion of AIDS patients, often associated with encephalitis.

US Secretary of Health and Human Services Margaret Heckler told the conference that AIDS is the chief health priority of the administration, but her speech, which studiously avoided mentioning the principal risk group, male homosexuals, did nothing to soothe the anger of homosexual activists and AIDS patients attending the conference.

Robert Gallo of the National Institutes of Health, who first isolated the virus known as HTLV-III, made a plea for less petty nationalism in the competition be- tween research groups in different countries. Gallo's plea was not immediately effective: the AIDS virus continues to be referred to by at least three different names depending on the affiliation of the speaker, despite agreement that the virus isolated by different groups is basically the same, and despite an informal agreement to call the virus HTLV-III/LAV (or LAV/HTLV-III) in recognition of the work of the French group under Luc Montagnier at Institut Pasteur in Paris. The name issue is to be tackled later this year by the International Committee on Virus Nomenclature. Gallo also took many by surprise by calling for an end to the cult of the instant media authority.

All the blood banks in the United States are now screening donated blood for AIDS virus using enzyme-linked immunosorbent assay test kits manufactured by commercial companies, but implementing the tests has not been without its problems. According to Gerald Sandler of the American Red Cross, an anomalously high proportion of samples tested with the Abbott Laboratories' kit produced evidence of AIDS antibody on first testing in some areas of the country, although the proportion of repeatedly reactive samples was close to the expected 0.2 per cent. Samples that produce positive results on two subsequent tests are confirmed by Western blotting, but it is apparently impractical to carry out Western blots on all samples that produce a positive result just once.

It is also becoming clear that after infection by the AIDS virus, several weeks or months may pass before antibodies reach easily detected levels; any test that looks just for antibodies can therefore be at best an imperfect protection for blood banks. In Britain, initial investigations of the Abbott test have produced disappointing results, and it seems most likely that Britain will develop its own test for blood banks rather than importing US products; price is also a factor.

There is still no agreement on whether US donors who show clear presence of antibody that is confirmed by Western blot should be told of the results of the test. The American Red Cross says it is still reviewing options, and organizations in different states are following different paths. California has adopted a moratorium on conveying test results to donors until alternative testing centres are established where people can be tested for antibody without giving blood.

The fear is that as long as testing is available only at blood collection centres, people in high risk groups will be attracted to offer their blood in order be tested: questionnaires indicate that most people in high risk groups do want to knows whether they have circulating antibody, despite the uncertain prognosis. Some federal funds are likely to be made available to establish several hundred alternative test centres, though the amount is still being argued.

Tim Beardsley 